\title{
'Gekontroleerde' eksegese en/of 'kreatiewe' uitleg
}

\author{
Ferdinand Deist
}

\section{Abstract \\ 'Controlled' exegesis and/or 'creative' interpretation}

Exegetes often regard epistemological questions as unnecessary and of 'academic' interest. Yet, answers to questions such as: 'What is a text?' and 'What is meaning?' are of fundamental importance in the argument about exegetical method(s). For instance, exegetical techniques focussing on the 'structure' of texts, although often claimed to be anti-positivist, do not of themselves imply a divorce from positivism, because the epistemological frameworks within which exegetical techniques are applied, determine their hermeneutical function. The influence of epistemological choices on the definition of the entities 'text' and 'meaning' as well as on the evaluation of textual expositions is discussed, and a few remarks are made on the (often determining) influence of theological tradition on such epistemological choices.

Watter is die mees geskikte metode(s) om 'n teks mee uit te lê? Dit is die soort vraag wat gewoonlik deur die eksegese-metodeleer ondersoek en beantwoord word. Om dergelike vrae te kan beantwoord, moet vrae soos: 'Wat is 'n teks?' en: 'Wat is betekenis?' eers beantwoord word. Ons vind sulke vrae dikwels erg 'akademies', alte teoreties en filosofies. Hierdie artikel wil aantoon waarom dit nie net van 'akademiese' belang nie, maar uiters noodsaaklik is om antwoorde op sulke voorvrae te verstrek voordat daar oor teks en betekenis gepraat kan word en voordat metodeleer aangedurf of ook maar net 'n oordeel oor 'n spesifieke uitleg uitgespreek kan word.

Om die probleem duideliker te kry, illustreer die eerste paragraaf die belangrikheid van die teoretiese raamwerk waarbinne 'n eksegeet homself bevind deur 'n (dikwels) veronderstelde 'noodwendige' wesensverskil tussen struktuuranalise en historiese kritiek te bespreek. Daarna word 'n voorbeeld gegee van 'lesings' van twee tekste en gewys hoe verskillende teks-definisies die oordeel oor die geldigheid van dié interpretasies beïnvloed. Laastens kom die vraag na wetenskapsteore- 
tiese en teologiese veronderstellings dan aan die orde om nogeens die noodsaak van teoretiese voorvrae aan te dui.

\section{VOORONDERSTELLINGS EN TEKSBETEKENIS}

Dit is ' $n$ algemene aanklag teen die histories-kritiese metode dat dit nie met die teks werk nie, maar met kousaliteite wat 'agter' die teks lê en daarom wesenlik 'n positiwistiese 'res' in ons eksegetiese mondering is. Maar is die tegniek van historiese kritiek noodwendig positiwisties en is ander tegnieke, byvoorbeeld struktuuranalise, vanselfsprekend nie-positiwisties?

Hermeneutiek het sy beslag gekry toe die geesteswetenskappe teen die einde van die negentiende en die begin van die twintigste eeu 'weggebreek' het van die wetenskapsideaal van die natuurwetenskappe (Hermand 1971: 3; Husserl 1954: 318). Daar is geargumenteer dat die natuurwetenskappe ten doel het om die natuur te verklaar, terwyl die geesteswetenskappe daarna streef om die menslike gees, soos dit in sy werke uitdrukking vind, te verstaan. Omdat die doelstellings van dié twee soorte wetenskap so grondliggend verskil, so het die argument verder geloop, moet hulle metodes ook grondliggend verskil: Terwyl die natuurwetenskappe hulle studieveld objektiveer, verinnerlik die geesteswetenskappe hulle studievelde deur inlewing (Einfühlung). Daarom is daar, in die literatuurwetenskap van die tyd, weggedoen met Ererbtes, Erlebtes, Erlerntes en die 'psige' of 'intensie' van die outeur as verklaringskategorieë vir literêre tekste en aangedring op metodes wat ons kan help om tekste deur inlewing te verstaan. Een van die duidelikste 'krete' in dié verband is dié van Leo Spitzer (1948: 2-4):

... we were never allowed to contemplate a phenomenon in its quiet being, to look into its face: we always looked at its neighbours or its predecessors - we were always looking over our shoulder. There were presented to us relationships of phenomenon $a$ and phenomenon $b$; but phenomenon $a$ and phenomenon $b$ did not exist in themselves, nor did the historical line $a-b . .$. It seemed indiscreet to ask what made them works of art, what was expressed in them.

Manon Maren-Grisebach (1970) stel die veronderstellings van dié twee benaderings in die volgende (weliswaar oorvereenvoudigde, maar tog nuttige) skema voor: 
Positiwistiese denke veronderstel:

Syn, wat in literatuur weerspieël word;

Werklikheid wat aan

literatuur voorafgaan;

Historiese feite;

Immanensie, wat literatuur as deel van die Diesseits bepaal;

Waarneming van die gegewene;

Noodwendigheid en kousaliteit, wat literatuur bepaal.
Geistesgeschichtlich-idealistiese denke veronderstel:

Denke wat literatuur voortbring;

Idee wat in literatuur te voorskyn tree;

Bowe-historiese 'wese';

Transendensie wat literatuur as metaphysicum bepaal;

Gees as skeppende krag;

Vryheid, wat literatuur outonoom maak.

Hierdie veronderstellings het dan, volgens Maren-Grisebach, bepaalde gevolge vir die metodes wat in elke raamwerk aangewend word.

Positiwisme:

Beskryf en dan verklaar; Betrekking op biografie; Rasionele analise; Induksie;

Konsentrasie op die objek as gegewe;

Liniêre denkpatroon wat kousale 'kettings' uitwys.
Geistesgeschichtliche idealisme:

Verstaan op grond van inlewing; Isolering van die kunswerk; Intuïtiewe sintese;

Deduksie;

Betekenis van die subjek/persoonlike bewussyn;

Sikliese denkpatroon wat strukture uitwys.

Maar as teksinterpretasie tekste as eiesoortige geestesgoed moet verstaan, wat is tekste dan? Sedert die opkoms van die fenomenologie as nie-positiwistiese kenstrategie het die vraag na die 'wese' van literatuur dié onderwerp van bespreking geword: Wat maak literatuur tot literatuur? Wat maak literêre taalgebruik anders as gewone taalgebruik? As jy afsien van allerlei kousale definisies, wat konstitueer dan ' $n$ teks (kyk in dié verband Pollmann 1971: 22-51; Ingarden 1968: 10-12)? Een van die antwoorde wat op dié vrae verstrek is, het vir dekades die denke oor tekste en hulle betekenis oorheers, naamlik: Dis die sigbare of onderliggende geheelstruktuur wat ' $n$ teks literêr maak. Betekenis is nou nie meer, soos in die positiwistiese literatuurwetenskap, gesien as 
iets wat 'agter' die teks in sy milieu, geskiedenis en outeur 'bestaan' nie, maar as iets wat in die teks voorhande is. 'n Literêre teks sou voortaan 'in sigself' verstaan word, dit wil sê aan die hand van sy eie struktuur en taal:

Was man eben noch als wissenschaftliche Entsagung hingestellt hatte, wird jetzt in aller Offenheit als Kleinigkeitskrämerei ... angeprangert. Die beliebtesten Schimpfworte waren dabei Motivriecherei, Parallellenjagd, ... worunter man eine Wissenschaft verstand, die durch ihre Beschränkung auf das Detail jeden Wertund damit Sinncharakter eingebusst hat (Hermand 1971: 3).

Dit het gelyk asof die negentiende-eeuse natuurwetenskap se invloed op die beskouing van wat (literatuur)wetenskap is, finaal die nek ingeslaan is: Voortaan sou ander uitlegkundige tegnieke in die literatuurwetenskap nodig wees, soos uit 'n vergelyking tussen die bostaande tipologieë en kenstrategieë van die twee denkrigtings blyk. Mettertyd het van dié kenstrategieë (tegnieke) ook praktyk geword in eksegese. Maar is die positiwisme daarmee uit die eksegetiese praktyk geweer?

Die antwoord op hierdie vraag, sover dit struktuuranalise aangaan, hang af van die vraag waar dié uitlegtegniek vandaan kom en in watter hermeneutiese raamwerk dit gepraktiseer word. Hoewel daar dikwels geargumenteer word dat struktuuranalise uit 'n radikaal ander denkraamwerk spruit as die historiese kritiek, is dit meer as waarskynlik dat dié twee tegnieke uit dieselfde 'stal' kom.

Eerstens: Vergelyk 'n mens die wyse waarop dié tegniek aangewend word met die tipologie van positiwistiese wetenskap hierbo, val die ooreenkomste op: Die teks word as 'n gegewene aanvaar, deur rasionele analise in sy onderdele ontleed en beskryf en dan word sy betekenis deur induktiewe argumentvoering uit die relasies tussen die onderdele verklaar.

Tweedens: Die enigste twee skynbare verskille tussen die struktuuranalitiese en positiwistiese werkwyse lê (a) in eersgenoemde se konsentrasie op strukturele eerder as op liniêre sintese en (b) in die weiering om 'n teks met verwysing na sy herkoms te verklaar. Dié tendense mag elemente van 'n 'geistesgeschichtliche' benadering tot literatuur weerspieël, maar dit mag net sowel kenmerke wees van 'n latere ontwikkeling in die positiwisme self, naamlik van die logiese positiwisme.

Die struktuurdefinisie wat in eksegetiese werke ter sprake kom, 
verskil normaalweg nie dramaties van wat Wilhelm Scherer (1978: 68) dié 'literatuurpositiwis' by uitnemendheid - onder 'Sprachatome' en 'mathematische Teile' as die onderdele van 'n omvattender 'Bedeutungskomplex' verstaan het nie. Boonop het dit 'n sterk (historiese) verwantskap met logies-positiwistiese metodologie: Die struktuurbegrip wat hier ter sprake is, is aan die generatiewe grammatika ontleen, wat 'n produk is van die logiese positiwisme. In soverre die struktuurbegrip dan inderdaad uit die logiese positiwisme kom, gaan dit nie meer werklik om strukture wat (induktief) aan die konkrete tekste ontworstel word nie, maar om ideële 'strukture' wat aan die onderliggende filosofie ontleen word. Vergelyk in dié verband Bamberg (1974: 46):

... daß mit 'Struktur' dann nicht mehr unbedingt Strukturen des realen Gegenstandes Sprache gemeint sein müßen, sondern das, was von vornherein als Struktur des idealen Gegenstandes 'Sprache' festgelegen worden sind....

Dieselfde geld ook die 'weiering' om 'n teks met verwysing na sy 'herkoms' te verklaar. Hoewel dié tendens ook in die 'geistesgeschichtliche' rigting aanwesig was, is dit net so 'n deel van die logiespositiwistiese metodologie. Vergelyk weer eens Bamberg (1974: 49):

Dadurch, daß Welt bzw Realität als Komplex oder auch Summe von Dingen und Gegenständen gefäßt wird und nicht als Komplex von Prozessen, muß die axiomatische Theorie die Raum-ZeitFaktoren als 'Störfaktoren' dem wissenschaftlichen Prozeß fernzuhalten versuchen, und kann nicht erkennen, daß sie im Grunde die Konstituenten der Wissenschaft selbst sind, insofern als gesellschaftliche wie naturhafte Prozesse ihren eigenen geschichtlichen Gesetzen unterliegen.

As ons sou argumenteer dat die struktuurbegrip van die struktuuranalise nie uit die logiese positiwisme kom nie, maar inderdaad uit die 'geistesgeschichtliche' filosofie, bly dit nog steeds 'n ope vraag of die gebruik van struktuuranalise noodwendig 'n breuk met die negentiende-eeuse natuurwetenskaplike ideaal van wetenskap impliseer. Die blote feit dat ' $n$ eksegeet ' $n$ bepaalde uitlegkundige tegniek (komende uit ' $n$ alternatiewe denkparadigma) toepas, is nog nie 'n waarborg dat hy of sy die (nuwe) denkparadigma waaruit die tegniek kom, deel nie. Maren-Grisebach (1970: 5) formuleer in dié verband soos volg: 
Es ist nicht ratsam, bei einzelnen technischen Arbeitschritten schon von 'Methode' zu sprechen; eine Methode wird erst konstituiert durch einen ganzheitlichen ideologischen Denkzusammenhang, in den einzelne Arbeitsschritte integriert sind. Als Weg ist der Methode Ausgangspunkt und Ziel inhärent, das heißt aber Zusammenhang.

Hoewel daar uit struktuuranalitiese oord sterk protes kom teen die 'kousale' verklaringswyses van byvoorbeeld die (destydse) historiese kritiek, word die struktuuranalitiese tegniek nog in 'n groot mate binne die raamwerk van dieselfde wetenskapsideaal aangewend:

Geïmpliseer in die denkraamwerk van struktuuranalitici sit daar dikwels, eerstens, die tipies (logies-)positiwistiese dichotomie van subjek en objek: Die teks (met sy struktuur) bestaan objektief buite die waarnemer en die waarnemer staan objektief teenoor die teks. Hy is die subjek en die teks die objek. Deur noukeurige rasionele analise en induktiewe(?) sintese kan die subjek die objek (verifieerbaar) ken, en dié kenproses vind plaas deurdat die subjek die objek in sy onderdele analiseer en as samehange interpreteer. Ken hy die onderdele en hulle funksionele samehang, ken hy die objek self, weet hy wat die teks beteken.

Tweedens: Die tipies positiwistiese kousaliteitsdenke het die ratio van struktuurstudies gebly. Die kousaliteitraamwerk is nou net van buite die teks na binne die teks verskuif. Nou was dit nie meer Erebtes, Erlebtes, Erlerntes agter die teks nie, maar Geformtes in die teks wat jou by die betekenis van ' $n$ teks uitgebring het: Omdat die struktuur van die teks só lyk, daarom is sy betekenis X. Die (oppervlakte- en/of diepte)struktuur van die teks is hier in effek die 'oorsaak' van die teks se betekenis. Vergelyk in dié verband Kovacs (1978: 88-89):

1. Consciousness has a structure which exists prior to all knowing and prior to all formulation of what is known.

2. This structure is universal to all consciousness, at least insofar as it is self-reflective consciousness.

3. Self-reflective consciousness arises only through and is mediated only by language.

4. The structures of consciousness underlie and are mediated through language at its deep structure ... the structures of consciousness correlate with structures of language. 
Dat strukturalistiese kunsteorieë in wese kousaliteitsteorieë is, het Kaufmann reeds duidelik uitgewys. Vergelyk byvoorbeeld:

Der Ursachebegriff [gehört] einer Metasprache [an], mittels derer über die Glieder einer Menge von atomaren Sätzen eine Teilung vollzogen wird, und zwar so, daß eine Zustandsbeschreibung (atomarer Satz), die einer Teilmenge angehört, welche in einer anderen Teilmenge enthalten ist, kausalen Vorrang hat gegenüber einer Zustandsbeschreibung, die der zweiten Teilmenge angehört $\ldots$ ausser man definiere den Ausdruck 'a verursacht $b$ ' durch ' $b$ folgt logisch aus a und Gesetzen'. Aber in diesem Falle ist entweder jede Erklärung eine Kausalerklärung, oder man fordert, daß die entsprechenden Gesetzen Kausalgesetze sind (Kaufmann 1976: $76-77,88$ ).

Derdens: Daar is stilswyend aanvaar dat, omdat ons oor teksbetekenis praat, daar so iets soos teksbetekenis is. Agter hierdie aksiomatiese aanvaarding lê daar ' $n$ bepaalde essensialistiese werklikheidsbeskouing wat ewe tipies van die negentiende-eeuse wetenskapsbeskouing was. En omdat daar so iets is as die betekenis van 'n teks, moet daar 'n metode wees om by daardie betekenis uit te kom. ' $n$ Teks is gevolglik gesien as 'n deposito van betekenis wat metodies ontgin en blootgelê moet word.

Hoewel die 'geistesgeschichtliche' struktuurkonsep dus aanvanklik bedoel was om die band van die positiwistiese benadering in die besturdering van geestesprodukte te breek, is die toepassing van 'n struktuuranalitiese tegniek - vir sover dit nie 'n produk van die logiese positiwisme is nie - geen waarborg dat ons aan dié negentiende-eeuse wetenskapsbeskouing ontkom het nie - as ons dan daaraan móét ontkom, soos dikwels in die polemiek teen die historiese kritiek aangevoer word.

Daarmee is nie gesê dat die struktuuranalitiese werkwyse 'verkeerd' is nie. Wat wél gesê word, is dat die redelik algemene aanvaarding, naamlik dat dié benadering op alternatiewe uitgangspunte gegrond is as die 'positiwistiese' historiese kritiek, waarskynlik 'n misverstand is: Is die wetenskapsteoretiese raamwerk waarin die struktuuranalitiese tegniek (ten minste hier te lande) aangewend word en vir sover dit nie 'n uitvloeisel van die logiese positiwisme is nie, wel wesenlik verskillend van die raamwerk waarbinne historiese kritiek destyds beoefen is en nog beoefen word? Of het ons dalk ses vir 'n halfdosyn verruil? 
Dat ' $n$ teks essensialisties opgeneem word as ' $n$ deposito van betekenis, dat 'n teks as ' $n$ objek buite die kenner gesien word, dat struktuur deur ' $n$ rasionele analise van die teks in sy onderdele 'blootgelê' word, dat dié blootgelegde elemente binne 'n (weliswaar gewysigde) induktiewe of logies-deduktiewe verklaringsraamwerk van kousaliteit aangewend word om by die betekenis van die teks uit te kom, lê nie in die struktuuranalitiese tegniek nie, maar is te wyte aan die wysgerige vertrekpunte van die beoefenaars van struktuuranalise. En as die wetenskapsteoretiese raamwerk eers die konteks omlyn waarbinne 'n tegniek deel van 'n metode word, lê die probleem nie in dié of daardie tegniek nie en sal verskillende tegnieke (soos struktuuranalise en redaksie-geskiedenis) hoogstens verskillende invalshoeke tot 'n teks bied, maar nie grondliggend ander vrae stel of ander antwoorde bekom nie. En dit is inderdaad die geval. Die argument tot dusver was dan ook net bedoel as ' $n$ voorbeeld van die soort misverstand wat kan ontstaan as ons alte vinnig voorgee dat ons by 'n sekere 'stadium' in ons denke 'verby' is en ons, ter bewys daarvan, op nuwe tegnieke beroep.

Enige tegniek wat aangewend word binne 'n denkraamwerk wat 'n teks beskou as ' $n$ deposito van betekenis, of dan betekenis sien as iets wat in 'n teks opgesluit lê, of dit nou al bekom word deur 'n tegniek wat die sensus literalis of die redaksionele outeurs-intensie of ook maar 'net' die betekenis van 'n teks 'soos hy daar lê', blootlê; enige metode wat 'n teks opneem as die kanon van sy betekenis of as iets wat die uitleg daarvan 'kontroleer'; enige debat oor die korrekte metode vir teksanalise om by betekenis uit te kom, deel in mindere of meerdere mate dieselfde teksbeskouing en daarmee min of meer dieselfde werklikheids- en wetenskapsbeskouing.

Ons moet dus versigtig wees om 'n òf-òf-houding in te neem in die debat oor eksegetiese metode, asof die toepassing van tegniek A (historiese kritiek) noodwendig iets radikaal anders oplewer as tegniek B (struktuuranalise). Dit mag blyk dat hulle premisse en vraagstelling, vir sover hulle binne dieselfde wetenskapsteoretiese raamwerk as leesstrategieë aangewend word, nie so dramaties van mekaar verskil as wat ons meen nie. Dit is nodig om eers die vraag te vra wat 'n teks en teksbetekenis binne 'n gegewe denkraamwerk is, voordat ons oor metode kan praat.

In die volgende paragraaf word werklike lesings van onderskeidelik 'n Ou- en Nuwe-Testamentiese teks gegee wat ons kan help om die implikasies van die voorafgaande argument helder te kry. 


\section{VOORONDERSTELLINGS EN TEKSDEFINISIES}

\section{1 'n Interpretasie van Genesis 28}

In 'n (nog) ongepubliseerde preek het ds Johan Gebhardt 'n interessante interpretasie aan die droom van Jakob by Bet-El gegee waarvan die basiese argument min of meer soos volg lui:

'n Mens droom gewoonlik oor dinge waarna jy baie uitsien of oor dinge waarvoor jy baie bang is. Jakob, wat sy vader 'n rat voor die oë gedraai het en sy broer verkul het, kom in sy haastige vlugtog by Bet-El aan, waar hy gaan slaap. En hy sien God, die Waker oor die reg, nie op sy troon gesete - soos die voorstelling altyd is nie - maar staande. Dit moes 'n nagmerrie-ondervinding vir 'n skuldige mens wees. Maar in plaas van 'n vurige oordeel oor dié bedrieër-vlugteling kom daar 'n sagte woord: 'Ek ken jou vader Isak en jou grootvader Abraham. Ek gaan saam met jou na die vreemde land toe.' Jakob, die bedrieër en skender van die reg, gaan onder engelebewaking verder: hy sal weer veilig in Kanaän terugkom. Daarmee sien God nie Jakob se onreg deur die vingers nie. Hy weet: verder aan in die toekoms sal Hy en Jakob mekaar nog wel van aangesig tot aangesig ontmoet: by Pniël. Dis waarom God Jakob gaan bewaar: met die oog op Jakob se bekeringservaring by Pniël.

Vervleg deur hierdie interpretasie word 'n verhaal oor die trou van God aan sy verbond vertel en ' $n$ troosboodskap aan die gemeente voorgehou.

\section{2 'n Interpretasie van Handelinge 8}

In 'n (ongepubliseerde) preek oor die ontmoeting tussen Filippus en die hofdienaar van Etiopië bou ds Francois du Toit ' $n$ beeld van die kamerling uit wat min of meer só lui:

Dié man is 'n eunug: $H y$ is ' $n$ verstote, verminkte, vereensaamde mens sonder die toekomshoop van 'n nageslag. Volgens die Ou-Testamentiese wet is so iemand nie eers in die vergadering van die gelowiges geduld nie. Hy soek vrede met homself, die wêreld en met God. Hy lees die teks uit Jesaja, maar ook dit verstaan hy nie. Maar dan, nadat die evangelie aan hom verkondig is, verander alles en kan die man sy reis met blydskap voortsit. 
Die eksistensiële 'toepassingsmoontlikhede' van hierdie lesing van die teks is voor-die-hand-liggend, en dis ook wat in die preek benut word.

\subsection{Vrae oor dié twee interpretasies}

Volgens alle gebruiklike kanons van teksinterpretasie moet 'n mens beswaar aanteken teen beide hierdie preke. In die geval van Genesis 28 word daar aanvaar dat Jakob skuldig gevoel het - dié probleem wat in die preek aangespreek word. Gevolglik is 'n soort psigo-analitiese 'inlees' gepleeg deurdat Jakob se droom as 'n 'nagmerrie' opgeneem is. Daarmee is ' $n$ belangrike kultuurhistoriese gegewe geïgnoreer: lemand wat wins uit ' $n$ transaksie kon maak (soos Jakob uit sy pot lensiesop) is indertyd eerder as wys, en daarom as geseënd, beskou. Trouens, in die volksmond sou: ' $\mathrm{Hy}$ het sy eersgeboortereg vir ' $\mathrm{n}$ pot lensiesop verruil' die onus vir die hele episode eerder op Esau laai en Jakob skotvry laat uitkom. Dit is ook 'n vraag of die idee van 'bekering', soos dit in moderne denke funksioneer, in die Pniël-episode ingelees kan word, veral gesien die moontlike godsdienshistoriese agtergrond en redaksiegeskiedenis van Genesis 32.

In die tweede geval sou 'n mens beswaar kon maak teen die interpretasie wat daar gegee is aan eunug, aangesien hoë amptenare destyds dikwels vrywilliglik ontman is. Daar is ook bewyse dat priesters in sommige Griekse kultusse hulle ter wille van die unio mystica laat ontman het en daarom mense van hoë aansien was. Boonop sê die teks self dat dié man met sy eie wa onderweg was én dat hy so pas 'n godsdienstige fees bygewoon het. Was hy dus so eensaam en verstote?

Dis maar ' $n$ paar van die talle moontlike besware wat teen dié interpretasies ingebring kan word - want hier is nie eers aandag gegee aan die strukture van die onderskeie perikope of hulle funksies in die groter vertellings nie. Die vraag is egter: Is die twee preke noodwendig verkeerd? Hulle sal slegs 'verkeerd' wees indien ' $n$ teks:

ontologiese status het;

' $n$ unieke inherente betekenis het wat metodies ontgin kan word; sodat 'n teks sy eie kanon van interpretasie daarstel,

en indien

dié of daardie rasionele, induktief-metodiese verbinding tussen elemente van die teks die kousale nexus tussen tekstekens (struktuur) en/of konteks (aan die een kant) en die betekenis van die teks (aan die ander kant) korrek kan ontsyfer om só die inherente betekenis van die teks 'bloot te lê'. 
Maar dit is juis die vraag: Is dit die enigste/korrekte definisie van 'n teks? Is ' $n$ teks iets wat op sigself en dus objektief bestaan, of is dit slegs swart tekens op wit papier wat eers deur my lees daarvan tot teks gemaak word? Word die teks dus gekonstitueer deur die outeursintensie of die lesersintensie? Het die teks sy eie kanon van betekenis of konstitueer my vraag aan die teks (of dan: my invalshoek tot die teks) sy betekenis vir daardie spesifieke lesing? Is die (gerekonstrueerde) struktuur of konteks van die teks die kader waarbinne die teks be-teken of verskaf die leser se (intuitief-bewuste) konteks en selfbewussyn daardie kader? Kontroleer die teks se tekens die betekenis wat daaruit afgelei word, of kontroleer die konteks van die leser die betekenis wat daaraan toegeken word? Wat is die verband tussen teks en betekenis? Is daar so iets soos 'n tekskontrole op betekenis of is daar net 'n konvensioneel-metodiese kontrole oor die lees-ervaring? Is daar so iets soos kriteria wat deur die teks voorsien word, of is die kriteria wat ter kontrole ingebring word, leeskonvensies van 'n gegewe era? Indien dit tekskontroles is, waarom verskil die leeskonvensies dan van era tot era en van skool tot skool? Hoe weet ons wat daardie tekskontroles is en of ons die regte tekselemente tot metodiese kontroles maak?

Hierdie teenstellende vrae hoef nie noodwendig telkens 'werklike' teenstellings te wees nie. Tog verteenwoordig dié teenstellings ten minste twee 'ekstreme' standpunte oor die definisie van 'teks'. Indien die een stel voorwaardes (waarin die teks as kanon van sy betekenis funksioneer) as uitgangspunt dien, is bostaande twee preke verkeerd. Indien die tweede stel aannames (waarin die leser 'n veel meer prominente rol vervul) telkens as uitgangspunt dien, is beide preke heeltemal aanvaarbare (kreatiewe!) interpretasies van die betrokke tekste, waarin die leeservaring die 'oorhand' het oor 'teks'-betekenis.

Dit is nie die bedoeling van hierdie artikel om bostaande vrae na dié of daardie kant te beantwoord nie. Bes moontlik sal 'n 'kompetente' leser van tekste beide stelle vrae bevestigend beantwoord en daarop aandring dat daar ' $n$ wisselwerking bestaan tussen 'teksbetekenis' en 'lesersbetekenis' (vgl Polanyi 1969). Die bedoeling is slegs om aan te toon dat bepaalde wetenskapsteoretiese vrae inderdaad bepalend is vir 'n besluit oor 'eksegetiese metode' en vir die (beoordeling van die) interpretasie van tekste. Of die antwoord nou ten gunste van die een of die ander of van albei uitval, feit bly ons sal onsself moet verantwoord ten opsigte van ons basiese vertrekpunte en nie maar net aanvaar dat ons, omdat ons dié of daardie tegniek aanwend, in ' $n$ bepaalde wetenskapsteoretiese 'kamp' aangeland het nie. Ek het hierbo probeer 
aantoon dat so 'n stilswyende veronderstelling foutief en misleidend kan wees.

\section{VOORONDERSTELLINGS AS KANONS VAN DENKE}

In die eerste paragraaf is daar gewys op die moontlikheid dat 'n mens, deur die leestegniek wat jy aanwend, mislei kan word om te dink dat jy in dié of daardie wetenskapsteoretiese kader tereggekom het, terwyl jy in werklikheid jou wetenskap met ' $n$ ander stel vooronderstellings kan bedryf as dié waarin die tegniek ontwikkel is. Solank 'n mens egter binne ' $n$ bepaalde wetenskapsteoretiese paradigma beweeg, sal die tegniek wat aangewend word, die resultate wat uit die beoefening van die wetenskap verkry word, nie dramaties beïnvloed nie. En die rede daarvoor is redelik voor-die-hand-liggend: 'n Bepaalde wetenskapteoretiese oriëntering deel bepaalde vooronderstellings, stel bepaalde soorte vrae en soek antwoorde op daardie vrae - met behulp van watter tegniek dan ook al.

Solank 'n eksegeet basies 'n essensialistiese werklikheidsbeskouing daarop nahou (in die Lockse sin van die woord), sal sy soeke wees na die 'essensies' van sy studie-objek - in ons geval na die (inherente) betekenis van 'n teks. En solank hy of sy 'n positiwistiese kenteorie aanhang, sal sy of haar wetenskap daarop ingestel wees om daardie essensies deur die analise en interpretasies van die eienskappe van sy studie-objek te ontdek - in ons geval deur die analise van die struktuur en/of die redaksiegeskiedenis en/of kulturele konteks van die konkrete teks. Of ons dan struktuuranalise as metode toepas of historiese kritiek of resepsiekritiek, sal net 'n verskil in fokus meebring, nie in wesenlike vraagstelling nie. Tradisioneel is ons metodes maar almal daarop ingestel om die betekenis van die teks te ontsyfer. Ons verskil wel oor die vraag of ons daardie betekenis metodies van dié of daardie kant moet benader, maar nie oor die vraag of die tekste betekenis het nie en ook nie oor die vraag of daardie betekenis gerekonstrueer kan word nie. Vergelyk in dié verband die volgende aanhalings uit die geskrifte van teoloë wat verskillende tegnieke van uitleg voorstaan, waar die relevante punte van ooreenstemming vet gedruk word:

De Bijbel is Gods Woord. Maar aan den anderen kant begeren we juist, omdat we ons aan de Schrift onderwerpen, de Schrift recht en zuiver te verstaan en zullen we al het mogelijke doen, om niet onze gedachten in de Schrift te brengen ... [en] rekening [te] houden met wat de Schrift zelf ons leert (Grosheide 1948: 5). 
Dit gaan in die eksegese om die verstaan van 'n bepaalde gedeelte. Ons eerste taak, nadat die teks vasgestel is, is dus om te bepaal wat staan daar (Verhoef 1973: 28)?

Das vorliegende Arbeitsbuch geht davon aus, daß zum Studienziel der Disziplin 'Altes Testament' nicht nur der Erwerb eines bestimmten Sachwissens, sondern vor allem auch die Aneignung der exegetischen Methoden zur Bestimmung des ursprünglichen Sinnes alttestamentlicher Überlieferungen gehört (Barth \& Steck 1971: $x$ )

Die Form stellt das Bezugssystem des Inhalts dar, zeigt also die Grenzen, auf die sich die Aussage des Textes beschränkt .... [Eine von außen herangetragene Fragestellung] muß ... im Bereich der Textaussagen bleiben und darf diese nicht übersteigen (Richter 1971: 177-178).

Dit is daarom ook nie merkwaardig dat ons almal, sy dit deur dié of daardie tegniek, op die end (byvoorbeeld met die oog op 'n preek) min of meer dieselfde betekenis 'uit die tekste haal' nie.

Hierdie eenstemmigheid is op sy beurt ook nie vreemd nie, aangesien die teologiese sisteem wat ons (ten minste in die Gereformeerde wêreld) as hermeneutiese raamwerk aanwend, en wat self sterk positiwistiese trekke vertoon (Van Huyssteen \& Du Toit 1982: 17-19), op 'n manier daardie teksdefinisie aan ons 'voorskryf':

a. In die klassieke Gereformeerde teologie word teologiese taal oorwegend - indien nie oorweldigend nie - as verwysings-uiting gesien (vgl Wethmar 1977: 152-153, 159vv). Dit wil sê, die woorde en sinne wat ons uiter, het 'n spesifieke referent en is daarom nie meerduidig of 'open-ended' nie.

b. Ons (teologiese) taalbeskouing is van huis uit essensialisties. Die 'essensies' waaraan ons taal uitdrukking gee, word vir ons deur die teologiese tradisie self deurgegee.

c. Die tradisionele sisteem is van huis uit kanonies-kontrolerend van aard en kan nie werklik voorsiening maak vir kreatiwiteit nie. Daarom stel dit ook die teologiese ensiklopedie voor as konsentriese sirkels rondom die Skrif, wat dan die finale Essensie (volledig/genoegsaam) bevat en daarom dié essensie van teologiese essensies is.

Van die Bybelse teks af bestaan teologie uit die rangskikking en 
herformulering van die essensies, wat via die teologiese denksisteem bekend is. Eksegese belig maar net hierdie sisteem, maar kan dit nie werklik verander nie. Her-skepping en veral skepping (kreatiwiteit) kán nie binne dié sisteem geakkommodeer word nie. Gevolglik kan 'n nie-essensialistiese werklikheidsbeskouing en teksteorie ook nie regtig binne dié denkraamwerk geakkommodeer word nie. En daarom sal ons preke soos dié wat in die vorige paragraaf aangehaal is, nie werklik binne hierdie denkparadigma as 'goeie' preke kan tipeer nie.

Op 'n manier sit ons met 'n groot probleem: Hoewel ons teoreties toegee dat ons (induktief) 'vanuit die Skrif' werk, vorm die geslote teologiese sisteem 'n deduktiewe hermeneutiese (èn wysgerige) raamwerk waarbinne ons werk. Ons probeer aan dié dilemma ontkom met behulp van die konsep 'hermeneutiese sirkel', maar die 'uitweg' systap die wetenskapsfilosofiese problematiek: Die teologiese sisteem is tradisioneel dogmaties en dus a-histories van aard. Die inbring van 'n historiese moment in die uitleg (aan die kant van die outeur of aan die kant van die uitlegger) relativeer egter die 'betekenis' van die teks en daarmee die teologiese 'essensies' van die sisteem wat uit dié teksbetekenis afgelei word - en daarmee die sisteem as sodanig.

Miskien is dit een van die redes vir ons keuse vir 'n uitlegtegniek wat die historiese kader van tekste vermy? Of kom dié teenkanting teen die 'historiese' meer uit ons (logies)-positiwistiese metodologie? Vergelyk wat Bamberg (1974: 49) in dié verband oor strukturalistiese metodologie skryf:

Konsequent weitergedacht muß man festhalten, daß die axiomatische Theorie nichts anderes als die bestehenden Verhältnissen beschreibt, indem sie sie als gegeben hinnimmt, nicht aber erklären kann und will, warum diese sich so entwickelt haben und wie sie sich in Rahmen der menschlichen Praxis weiterentwicklen werden. Logisch-empiristische Forschung eliminiert über die Raum-Zeit-Faktoren die konkrete Geschichtlichkeit und zielt auf eine logisch-überzeitlichen Wahrheit.

Miskien gaan dit hier nie om 'n òf-òf van teologiese sisteem òf wetenskapsfilosofiese vertrekpunte wat ons keuses beïnvloed nie, maar daarom dat ons (logies-)positiwistiese metode maklik kombineer met die naïef-realistiese kenteorie wat ten grondslag van ons teologiese sisteem lê? 


\section{SLOTSOM}

Dit is nie die bedoeling van hierdie artikel om regter te speel oor 'reg' en 'verkeerd' nie - ook nie oor die 'reg' of 'verkeerd' van die Gereformeerde denkraamwerk nie. Dit gaan per slot van rekening hier oor die mees fundamentele keuses van wêreldbeskouing, waar 'reg' en 'verkeerd' seker nie meer geld nie. Die keuse tussen, of die oorbrugging van die 'kloof' tussen realisme en nominalisme - waaroor dit in wese nog steeds hier gaan - is nie van gister af met ons nie. Niels Bohr het iets gesê soos: 'The opposite of a triviality is an untruth, but the opposite of a profound truth is another profound truth.' Dit is bes moontlik ook hier die geval. Die vraag of 'n teks betekenis 'het', of die lees daarvan eers die teks (en so ook sy betekenis) 'konstitueer' en of albei sienings op ' $n$ manier 'waar' is, word dus hier oopgelaat.

Wat ek probeer aantoon het, is dat ons, hoewel ons voorgee dat ons ons wetenskap duskant die Methodenstreit bedryf, dikwels met 'n (ondeurdagte) denkraamwerk opereer wat nie juis verskil van die negentiende eeu s'n vóór die Methodenstreit nie en dat ons nie altyd genoegsaam bewus is van die mees grondliggende probleme wat deur ons vak geïmpliseer word nie. Ek wou ook aantoon dat ons, in ons besinning oor teksteorie en eksegetiese metodes, werklik fundamentele vrae behoort te stel - ook ten opsigte van ons eie, gevestigde (teologiese) denktradisies - wat ons meestal maar as vanselfsprekend veronderstel. As 'wetenskap bedryf' onder andere beteken om krities en kreatief besig te wees, is een van die voorvereistes sekerlik om bewustelik besig te wees met wat jy doen. As dié artikel daarom daartoe kon bydra dat ons ons werk net meer bewustelik doen, sodat ons gesprekke op tersaaklike probleme konsentreer, het dit sy funksie vervul.

\section{Literatuurverwysings}

BAMBERG, M 1974. Generativismus - Logischer Empirismus - Strukturalismus: Versuch einer wissenschaftstheoretischen Einordnung und Kritik der Generativen Poetik. LingBibl 33, 34-63.

BARTH, H \& STECK, OH 1971. Exegese des Alten Testaments: Leitfaden der Methodik. (2. erg Aufl). Neukirchen-Vluyn: Neukirchener Verlag.

BLEICHER, I 1983. Contemporary hermeneutics: Hermeneutics as method, philosophy and critique. London: Routledge \& Kegan Paul.

GROSHEIDE, FW 1948. De bevooroordeeldheid der exegese. Kampen: Kok.

HABERMAS, J 1977. A positivistically bisected rationalism in Adomo, TW et al, 1977. The positivist dispute in German sociology. Transl by G Adey \& D Frisby. London: Heinemann. 
HERMAND, J 1971. Literaturwissenschaft und Kunstwissenschaft. Stuttgart: Metzler.

HUSSERL, E [1936] 1954. Die Krise der europäischen Wissenschaften und die tranzendentale Phänomenologie, in Biemel, M (Hrsg), Husserliana, Bd VI. Den Haag: Martinus Nijhoff.

INGARDEN, R 1968. Vom Erkennen des literarischen Kunstwerks. Tübingen: Niemeyer.

KAUFMANN, JN 1976. Löst der Strukturalismus die Kausalanalyse auf? ZAWT 7, 75-98.

KOVACS, BW 1978. Philosophical foundations for structuralism. Semeia 10, 85-105.

MAREN-GRISEBACH, M 1970. Methoden der Literaturwissenschaft. Bern: Francke.

POLANYI, M 1969. Sense-giving and sense-reading in Gill, JH (ed), Philosophy today No 2, 278-310. London: Macmillan.

POLLMANN, L 1971. Literaturwissenschaft und Methode, Bd I. Frankfurt: Athenäum.

POPPER, KR 1974. The logic of the social sciences, in Adorno, $\mathrm{T} W$ et al, 1977. The positivist dispute in German sociology, 87-122. Transl G Adey \& D Frisby. London: Heinemann.

PROX, L 1972. Strukturalistische Kunstforschung. ZAWT 3, 285-297.

RICHTER, W 1971. Exegese als Literaturwissenschaft: Entwurf einer alttestamentlichen Literaturtheorie und Methodologie. Göttingen: Vandenhoeck.

SCHERER, W 1878. Zur Geschichte der deutschen Sprache. Berlin: Weidmannsche Buchhandlung.

SPITZER, L 1948. Linguistics and literary history: Essays in stylistics. Princeton: Princeton University Press.

VAN HUYSSTEEN, JWV \& DU TOIT, B 1982. Geloof en Skrifgesag. Pretoria: N G Kerkboekhandel.

VERHOEF, PA 1973. Metodiek van eksegese. Kaapstad: N G Kerk-Uitgewers.

WETHMAR, CJ 1977. Dogma en verstaanshorison. Amsterdam: Rodopi. 